International Journal of Engineering \& Technology, $7(3.2)(2018) 770-773$
International Journal of Engineering \& Technology
SPC
Website: www.sciencepubco.com/index.php/IJET
Research paper

\title{
Applying ELMS Technology Based Teaching Strategy to Improve Writing Competence for EFL Remedial Students across Different Motivation Level
}

\author{
Sujito $^{1 *}$, Nuning Kurniasih ${ }^{2}$, Wildan Mahir Muttaqin ${ }^{1}$, Ifit Novita Sari ${ }^{3}$, Andre Paulus Saleky $^{4}$, Patma Tuasikal ${ }^{4}$, \\ Yani Talakua ${ }^{4}$, Beatus Mendelson Laka ${ }^{5}$, Amelia Niwele ${ }^{5}$, Firman Aziz $^{6}$ \\ ${ }^{1}$ Department of English Language Education, IAIN Surakarta, Surakarta, Indonesia \\ ${ }^{2}$ Faculty of Communication Sciences, Library and Information Program, Universitas Padjadjaran, Bandung, Indonesia \\ ${ }^{3}$ Department of Social Science Education, Post Graduate Program, Universitas Kanjuruhan Malang, Malang, Indonesia \\ ${ }^{4}$ Civic Education Program, STKIP Biak, Biak, Indonesia \\ ${ }^{5}$ Elementary School Teacher Study Program (PGSD), STKIP Biak, Biak, Indonesia \\ ${ }^{6}$ Department of Communications, Universitas Pendidikan Indonesia, Bandung, Indonesia \\ *Corresponding author E-mail: sujitodoktor@gmail.com
}

\begin{abstract}
Technology provides an alternative to improve learning outcomes in new ways. ELMS (Edmodo Learning Management System) technology based teaching is expected to provide solutions in teaching English in Indonesia, especially for teaching writing. This research is to determine how application technology can improve the writing ability of remedial students who are low motivated. This study was aimed to see the difference of the remedial students' writing competence before and after taught using ELMS teaching technology by considering learners' motivation level. This study used experimental design using factorial design $2 \times 2$. Two classes of remedial learners consisted of 30 students for each group was assigned into 2 smaller groups to match with their motivation falling into two classifications: high and low motivation. The two groups were given treatment for about 7 meetings. The study revealed three findings. First, learning achievement of the subjects after given subtext application teaching technology was higher than the subjects given conventional non technology media writing. Second, the learning achievement of the subjects having high motivation was higher than the learning achievement of the subject with low motivation. Third, there was significant interaction between the use of application teaching technology with the subjects' motivation level towards writing achievement improvement of the first year remedial EFL students.
\end{abstract}

Keywords: teaching technology, Edmodo, motivation, remedial students, writing

\section{Introduction}

In Indonesia where English is learned as foreign language, the students have to learn all four English skills. They are listening, speaking, reading, and writing. Writing as the most difficult skill among the four skills is meant to use in communication when people cannot talk directly. Writing is considered as a productive skill. Writing is used for communication to others for specific purposes. In the context of learning, writing can provide an opportunity for the students to express their ideas through. By writing, students can develop their concepts and ideas of a certain problem by organizing them on paragraphs. Besides, writing is a complex activity and cognitively demanding as well. In short, writing skill is the most complicated one for English as foreign or second language learners.

Writing is factually the most effortful skill that language learners can implement. Indeed, by fact writing skill has many difficult and complicated rules. The rules govern in every word that would be written to express the writer's ideas, grammatical structure and idea organization. Developing the ideas to the paper is not the only competence but also attending the rule in writing process carefully as well. In learning writing, students need to learn the basic point of how to write well as the required exercise. The competence of the students in writing is not just putting words in arrangement into sentence, composing paragraphs by linking sentences, and building a text through ordering the paragraphs. Moreover, the students are required to understand and apply grammatical and lexical knowledge. Spelling, punctuation, capitalization and grammar are some sub-skills of writing competence that some of those are trained to the students in elementary level [1]. Besides, understanding and mastering many vocabularies, grammar, spelling, punctuation, and other writing elements required to writing composition are quite necessary for the writing learners. In short, it is obvious that writing skill is the most difficult one among those four language skills.

This study researcher aims at finding the empirical phenomenon on the issues concerning with learning writing of EFL students, especially in English Department of IAIN Surakarta. The observation done by the researcher as preliminary study to the English lecturer and the second grade students of English Department of 
IAIN Surakarta, most of the students there are considered the low achiever in producing a good paragraph composition. It seems that most of them get some problems in composing English text well.

As explained in the above part, the pre-research conducted by the researcher in observation to the second year EFL students of English Department of IAIN Surakarta showed that there were a lot of students as low achiever. They have still big difficulties in writing English composition. It was proved by the fact that when those students followed the writing instruction process to compose paragraphs or text, they looked very confused. In the process of producing the paragraphs or composition the students tended to copy from the example given by the teacher although the teacher also gave explanation to the students about how to compose a paragraph or text in sequential process to produce their own genuine composition. By the observation, it was watched that the students seemed confused of the general structure and organization of the text when they composed starting from making good sentences and arrange them into writing text. It was so far known from the observation that the students could not produce good sentences because of their lacking of vocabularies. Moreover, the students seemed got still the difficulty to the pattern of the tenses that used in text they composed. The students still got confused when they have to arrange the sentences into text using the generic structure and linguistic features of the text.

Based on that specific predictive and empirical rationale above, the researcher conducts a research to the second year EFL English Department of IAIN Surakarta's students. Not only did observation, the researcher also delivered interview section to the English lecturer teaching those students and observed the facilities used in this institution. The results of interview and the further observation are like the following. There were some facilities owned by the institution. Besides having a good language laboratory, English Department of IAIN Surakarta had also good facilities available in the classroom. Some multimedia LCD and video recorder were also available. It seemed that the teacher were accustomed to use adequate media to teach the student. The teacher was accustomed to use power point media in teaching writing for the students. However it seemed that the teacher got problem to make the use of the media optimally. It was frequently the teacher used module only with some conventional non- technology based teaching to teach the students. That condition made the students drown in boredom. They got less interest in following teaching learning process. Therefore most of the students got low scores in writing achievement and some of them should follow the remedial class program.

Nowadays, the teacher is required to utilize media to deliver the teaching material optimally in teaching learning process. It will be full of fun, interesting as well as challenging teaching learning activity hence the students could grasp the teaching material clearly and comfortably in the classroom. In this research the researcher used. Along with the times, applying technology into teaching is very important today [2]. In teaching teachers should pay attention to the principle of application of technology in the classroom. Important technology is used by teachers to provide students with new and meaningful experiences [2]. Besides, technology can create new media in teaching and learning that result in interesting and interactive learning environment [3]. One of the newest technologies that teachers can use is Edmodo Learning Management System (ELMS) Technology Based Teaching Technology Based Teaching. ELMS is a modern teaching technology application designed for educational purposes [4]. ELMS teaching application technology is able to help students in learning. ELMS can be applied in teaching writing. Several studies have proven empirically [5] that Edmodo Learning Management System can be applied in teaching writing. This research is intended to test the effect of application of ELMS technology to improve remedial EFL students' writing skills.

The purpose of the Writing Course is to give students the ability to write paragraphs. In terms of providing students with the ability to write this paragraph, the provision of teaching with Edmodo
Learning Management System (ELMS) technology is as an alternative. In the classroom there are some students who have difficulty in expressing their ideas into the style of writing. These students experience learning delays and they are included in the remedial program. Students in this remedial program are students who have a learning score under 60 from a maximum scale of 100 . In the English Department of IAIN Surakarta, the remedial class program aims to accommodate and provide material enrichment to study participants who are deemed to experience delays in learning. This study was conducted to find answers to the following questions. The problem in this study is basically to find out: (1) differences in the ability of writing remedial class students in Writing Course with Edmodo Learning Management System (ELMS) based technology teaching compared with teaching without Edmodo Learning Management System (ELMS) technology base (2) differences in learning results of students writing remedial classes with different levels of motivation and (3) the interaction between the use of Edmodo Learning Management System (ELMS) technology based and the motivation level on the improvement of students' writing skills in the remedial class.

The research by applying ELMS technology based teaching strategy aims to know whether it can improve writing competence for EFL remedial students significantly. This research is aimed also at determining whether the effect of ELMS to the students' writing achievement improvement interact with the students motivation in different level. It is expected that, students' motivation give additional effect to the application of ELMS technology based teaching strategy to get optimum improvement of students' writing achievement. The result of this research is expected also to be as a further reference to improve EFL students' writing achievement for writing teacher. The result of this research may intentionally give suggestion to the university management to apply new teaching technology in teaching learning process especially writing.

\section{Methodology}

\section{A. Procedure}

In this study, an experimental research with a quantitative approach is applied. Experimental research is the best way to apply in cause-and-effect relationship research.

In this study, ELMS technology based teaching was independent variable expected to give effect. Whereas, students writing skill was variable given effect. Motivation level is as moderator variable. The factorial design was applied to measure used to the main effect of ELMS technology based teaching as treatment to the dependent. To obtain the data, the post-test only with control group design was administered.

\section{B. Treatment}

Treatment in the form of giving differential technology application in writing instruction was applied to all those four experimental group research subjects. The first group as experimental group will be given a treatment (ELMS technology based teaching), the other group, and the control group was taught with conventional teaching technique without new technology based approach. Posttest was administered to the all subjects after treatment to measure the achievement of the subjects' writing skill. It was the score of the post-test that was used as raw data to be analyzed further.

The target population of the study research is first year EFL students of English Department of IAIN Surakarta consisting of 7 classes. Every class consists of 40 students. The total number of population is 280 students. The samples of this research are 70 slow learner students (having less than 60 score of the previous assessment). The 70 students are assigned into two groups; the first group is as experimental class in which ELMS based teaching is applied. Another group as control group in which the conventional non specific technology based teaching was implemented was exposed with 6 meetings. Before the experiment is begun, all the 70 students are given questionnaire to measure their motivation level. 
As explain above, quantitative approach was used in this study. The quantitative data in the form of number are the result of students' writing test of both subject groups obtained from post-test administration. This study administered writing test in the form of essay test to measure the students' achievement of writing composition both experimental and control classes after given treatment By administering the test, it was detected which group will get high score compared to another. To get the test validity and reliability, try out of the test was conducted to the students of English Department of IAIN Surakarta in other classes that were not included in experimental group and control group involved in this study. In composing the test, role of language testing experts was taken into consideration by involving them in giving the outline of the test. In scoring the test, this research used inter-rater scoring. By using inter-rater technique the reliability and validity of the scores were guaranteed. The researcher acted as the first rater. He gave the score of the students writing work. The second rater was the writing lecturer of those classes. There are five aspects used as the basis of scoring. Those five aspects are: language use, vocabulary, content, organization and mechanic device use (punctuation).

\section{Results and Discussion}

The data were obtained after the post-test was administered. The post-test were administered to measure the effect of using ELMS technology based instruction in teaching writing. The mean of experimental and control class were compared. The data were analyzed to test the hypothesis that had been formulated. The following is testing the first partial effect of treatment that is using ELMS technology based instruction to subjects' learning writing achievement. Then, it was continued with testing the second partial effect of moderator variable that is motivation to subjects' writing achievement.

The purpose of the analysis in this section is to determine whether there is any effect of applying analogy variation on subjects' learning achievement across cognitive style. The description of the data is displayed using histogram in order to be easy to grab in single view. The following histogram shows the condition of the experimental subjects and control subjects' writing achievement after treatment.

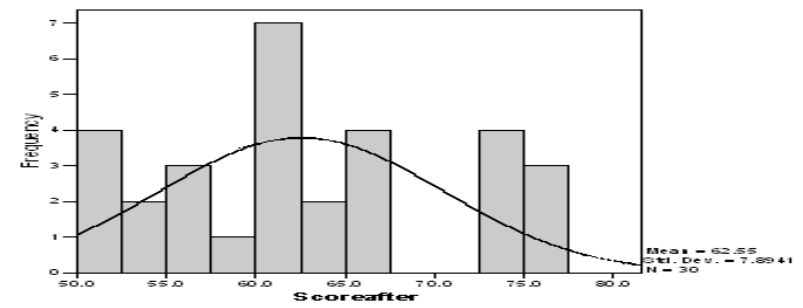

Fig.1: Histogram of After Treatment Scores of Writing Achievement of the Control Group

The histogram shows that the experimental subjects' achievement is better that the control subjects achievement. Histogram

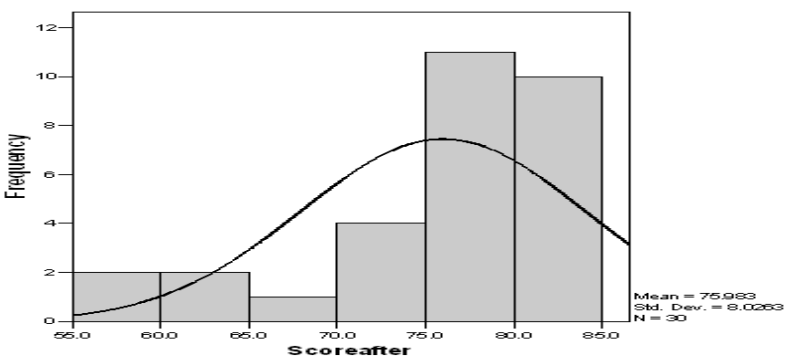

Fig.1: Histogram of After Treatment Scores of Writing Achievement of the Experimental Group

Table 1 gives a description that the F-ratio for teaching technique is 6.315 with the degrees of freedom 2. The P-value is .002. This research uses significance level $.05(\alpha=.05)$. It can be interpreted that there is significant different mean score of the students' learning achievement after being taught using written analogy and oral analogy.

Table.1: Tests of Between-Subjects Effects

\begin{tabular}{|l|r|r|r|r|r|}
\hline \multicolumn{1}{|c|}{ Source } & $\begin{array}{l}\text { Type III Sum } \\
\text { of Squares }\end{array}$ & Df & Mean Square & F & Sig. \\
\hline Corrected Model & 5688.274 & 4 & 738.803 & 10.224 & .000 \\
\hline Intercept & 1167055.22 & 1 & 1278166.303 & 17062.081 & .000 \\
\hline $\begin{array}{l}\text { Non/ELMS varia- } \\
\text { tion }\end{array}$ & 853.380 & 2 & 482.184 & 6.304 & .002 \\
\hline Motivation Level & 433.152 & 3 & 289.570 & 3.503 & .028 \\
\hline $\begin{array}{l}\text { Non/ELMS varia- } \\
\text { tion * Motivation } \\
\text { level }\end{array}$ & 4191.732 & 5 & 1211.850 & 17.550 & .000 \\
\hline Error & 18441.000 & 261 & 74.902 & & \\
\hline Total & 1203407.000 & 270 & & & \\
\hline Corrected Total & 25251.585 & 251 & & & \\
\hline
\end{tabular}

a R Squared $=.251$ (Adjusted R Squared $=.234)$

Therefore, the inference of this analysis as the first research finding shows that there is significant different effect of using ELMS technology based instruction to slow learner students' achievement in writing text.

Table.2: Estimated Marginal Means of Teaching Variation

\begin{tabular}{|c|c|c|c|c|}
\hline \multirow[b]{2}{*}{$\begin{array}{l}\text { Technology Based } \\
\text { Teaching Variation }\end{array}$} & \multirow[b]{2}{*}{ Mean } & \multirow[b]{2}{*}{$\begin{array}{l}\text { Std. } \\
\text { Error }\end{array}$} & \multicolumn{2}{|c|}{ 95\% Confidence Interval } \\
\hline & & & $\begin{array}{l}\text { Lower } \\
\text { Bound }\end{array}$ & $\begin{array}{l}\text { Upper } \\
\text { Bound }\end{array}$ \\
\hline 1=Non ELMS & 65.699 & .801 & 63.692 & 66.375 \\
\hline $2=\mathrm{ELMS}$ & 70.162 & .801 & 67.365 & 72.079 \\
\hline
\end{tabular}

From the result of analysis of estimated marginal means, as shown in Table 2, the rank of the two groups is known. The highest mean score of learning achievement is achieved by the group of students given ELMS. The second position is achieved by the group of students taught non-ELMS.

Table 3 displays that students' achievement average of high motivated students is 70.830 . The mean of low motivated students 67.512. In terms of the rank, the highest performance is achieved by high motivated students. The second is achieved by the low motivated student group.

Table.3. Estimated Marginal Means of Motivation Level

\begin{tabular}{|c|c|c|c|c|}
\hline \multirow[b]{2}{*}{ Motivation Level } & \multirow[b]{2}{*}{ Mean } & \multirow{2}{*}{$\begin{array}{l}\text { Std. } \\
\text { Error }\end{array}$} & \multicolumn{2}{|c|}{$95 \%$ Confidence Interval } \\
\hline & & & $\begin{array}{l}\text { Lower } \\
\text { Bound } \\
\end{array}$ & $\begin{array}{l}\text { Upper } \\
\text { Bound } \\
\end{array}$ \\
\hline $\begin{array}{l}\text { 1=High Motivated } \\
\text { Students }\end{array}$ & 69.034 & .790 & 67.237 & 70.830 \\
\hline $\begin{array}{l}2 \text { = Low Motivated } \\
\text { Students }\end{array}$ & 65.722 & .800 & 64.026 & 67.512 \\
\hline
\end{tabular}

This point proposes discussion of research finding. It is about the explanation of result of the research related with the relevant some constructs and some logical explanation. In this part, it will be discussed the theories that support research findings. As shown in the previous table the mean score of experimental group subjects is 72.079. This mean score is higher than the mean score of subjects in control group (66.375). By this fact, it is obvious that teaching writing in experimental class by using ELMS technology based teaching can encourage students to be more interested in learning. They seem also motivated to learn and follow writing activity. ELMS technology based teaching as a new teaching technique can arouse teaching and learning atmosphere in the classroom to be more comfortable. The students' boredom in following teaching and learning process is significantly decreased. Therefore, the mean score of students in experimental class is better than 
students in control group implying that the EFL slow learner students' writing competence improves significantly after given ELMS technology based instruction.

On the other hand, this research finding shows that the mean score of research subjects in control group is 66.375. It is lower than the experimental group score. It means that the process of teaching writing in control class using conventional non-technology based teaching cannot make the remedial students motivated. The students in remedial class unavoidably need challenging, interesting and new teaching learning atmosphere to lose their boredom of the material presented and the writing composition exercised. The use of non-ELMS based instruction which is considered old-fashioned instruction make the unmotivated to do the process of writing. Their motivation to follow the learning process is not as high those given ELMS based instruction. It is proved by the data of motivation and achievement presented in the previous part that the high motivated students that mostly from experimental group get better mean score (70.830) that those in control group (67.512).

Teaching using ELMS technology is also able to facilitate cognitive processes for students in writing. Writing is not only creating products [6] but also involving process [7]; [8]. Cognitive processes in writing activities cannot be ignored. Cognitive processes such as composing, synthesizing ideas, and writing publications are forms of thought-provoking activity [9]. This not only applies in paper-based writing, but also writes in a multimedia environment. Teaching using ELMS technology is able to facilitate cognitive processes for students in the learning process of writing.

As shown above this research found that the students in experimental group who are taught by using ELMS technology based teaching have higher performance in writing composition than those given conventional non technology based teaching. The analysis of that fact can be clarified by the following reason. Instructional media, including ELMS in this research, is any devices of techniques utilized to deliver the teaching material from the teacher to students. Therefore, the instruction media are expected to arouse the learners' motivation, thought, and interest [10] . The teaching learning process requires an appropriate and challenging instructional media to deliver the teaching material to students. Instructional media have significant function to succeed teaching learning process. The instructional media helps affecting the success of teacher in transferring the knowledge to the students by attracting the students' motivation and interest. The main point of teaching learning process is to reach the good achievement of the student. Therefore, the use of instructional media or technique like ELMS really make the students more motivated to learn and get success in achieving high learning performance.

On the other hand [11] propose that instructional media are any device utilized to send the content of instructional material to the students. The instructional media may include books, video, recorder, picture, film television, photograph, computer and now teaching technology application like ELMS, Subtext etc. Using the new instructional media is required by the teacher to make the teaching is effective. Instructional newest media such as ELMS and Subtext are tools having crucial function to make teaching learning process effective to deliver the teaching material. ELMS help affecting the effectiveness of the teacher in transferring the knowledge for the students. It supports the teacher in setting up the interesting and motivating teaching learning process.

In line with the scholars' theories supporting the finding of this research, it can be inferred that using ELMS technology based teaching to teach writing skill is recommended. It makes the EFL low achiever students more motivated and increases their writing performance.

Using ELMS technology based teaching not only increases the general writing achievement of EFL remedial students but also increases the level of students' motivation. Moreover, when it is put in interactive effect relation, the EFL low achiever students having high motivation get very good achievement in writing than those achieved by low motivation students. This fact reveals that the use of new instructional media by the teacher will be more effective if the students whom the media exposed to have high motivation. Even the new challenging technology based teaching media will not work effectively when the students are in low motivation. Therefore, at last it can be inferred that using ELMS technology based teaching gives significant betterment of EFL remedial students' writing performance.

\section{Conclusion}

Teaching of writing based on ELMS technology is able to significantly increase the writing ability of the remedial class. Highly motivated remedial students are able to achieve high achievement in writing when they are taught to write using ELMS technology. Empirical facts imply that remedial class students prefer a technology-based teaching approach because they have high motivation in learning. Remote students with high motivation levels prefer technology-based teaching to improve their achievement

\section{Acknowledgement}

This research was conducted in IAIN Surakarta. In this occasion we would like to send our gratefulness to the university. We would like also express our gratefulness thank to the participants and subjects of the study and the people who helped collecting the data: Rina Widjajanti and Wildan Mahir Muttaqin.

\section{References}

[1] S. Cornbleet and R. Carter, The Language of Speech and Writing. 2001.

[2] T. Erben, R. Ban, and M. Castañeda, Teaching English language learners through technology. 2008.

[3] N. Kurniasih et al., "Prototype Application Hate Speech Detection Website Using String Matching and Searching Algorithm," Int. J. Eng. Technol., vol. 7, no. 2.5, pp. 62-64, Mar. 2018.

[4] C. Kongchan, "How Edmodo and Google Docs Can Change Traditional Classrooms," in The European Conference on Language Learning, 2013.

[5] D. Adas and A. Bakir, "Writing Difficulties and New Solutions : Blended Learning as an Approach to Improve Writing Abilities $\mathrm{PhD}$ in teaching English Language Methods, AL-Quds Open University," Int. J. Humanit. Soc. Sci., 2013.

[6] M. Saville-Troike, Introducing second language acquisition. 2006.

[7] H. D. Brown, "Teaching by principles: an interactive approach to language pedagogy," Tesol Q., 2001.

[8] T. Practice and E. L. Teaching, "The Practice of English Language Teaching (3rd ed.).," Spring, 2003.

[9] D. R. Krathwohl, "A Revision of Bloom 's Taxonomy: An Overview," Theory Pract., 2002.

[10] A. dan B. Usman, "Media Pembelajaran," Meedia Pembelajaran, 2002.

[11] A. Azhar, "Media Pembelajaran," Meedia Pembelajaran, 2008. 